\title{
Effects of Electromagnetic fields on the
} Physicochemical Properties of Waste Water Samples from Selected Industries in Akure Metropolis.

\author{
Boboye B. ${ }^{1}$, Adetuyi F. C. ${ }^{1}$, , Balogun O. B. ${ }^{2}$ \\ Department of Microbiology Federal University of Technology, Akure Ondo State, Nigeria. \\ Department of Microbiology Joseph Ayo babalola University, Ikeji-arakeji Osun State, Nigeria.
}

\begin{abstract}
Wastewater is one of the most critical problems of both middle and low income countries is improper management of vast amount of wastes. The research is to determine the physicochemical characteristics of the wastewaters and also to asses the effect of the Electromagnetic field (EMF) on the physicochemical factors of the waste watersWaste water samples were collected from two industries in Akure Metropolis. The waste water samples were subjected to physicochemical analyses before and after exposure to Electromagnetic field (EMF) at 1150nT, 1310nT, 3000nT, 5000nT. The presence of some bacteria in the waste water collected from different companies showed their occurrence at different hours during the treatment of the wastewater sample with different EMF strength. a. From the two industries, before EMF treatment industry A had the highest $p H$ value (7.74), Temperature $\left(27.00^{\circ} \mathrm{C}\right)$, Total Solid $(277.00 \mathrm{mg} / \mathrm{l}$.$) , Total$ Disolved Solids (256.00mg/l.) Industry B had Total hardness (994mg/l), Chemical Oxygen Demand $(13.20 \mathrm{mg} / \mathrm{l})$, Potassium $(13.23 \mathrm{~g} / \mathrm{l})$, Biochemical Oxygen Demand $(9.60 \mathrm{mg} / \mathrm{l})$ Zinc (1.24ppm) and Copper (0.07ppm). From the two industries, after EMF treatment $\mathrm{pH}$ (6.47), Turbidity (0.29NTU), Biochemical Oxygen Demand (4.60), Chemical Oxygen Demand (5.40). Industry B had Chloride $(10.47 \mathrm{mg} / \mathrm{l}),(600 \mathrm{mg} / \mathrm{l})$. Sulphate $(8.70 \mathrm{mg} / \mathrm{l})$, after exposure to EMF, the values above listed shows physicochemical factors reduced significantly. Therefore from the study, it was observed that EMF treatment has a significant effect on the bacteria load and physicochemical condition of the waste water samples.
\end{abstract}

Keywords- Wastewater, Electromagnetic field, Microorganisms, bacteriological analysis.

\section{INTRODUCTION}

Wastewater, is any water that has been adversely affected in quality by anthropogenic influence. Is one of the most critical problems of developing countries is improper management of vast amount of wastes Wastewater can originate from a combination of domestic, industrial, commercial or agricultural activities, surface runoff or storm water, and from sewer inflow or infiltration (2). Municipal wastewater (also called sewage) is usually conveyed in a combined sewer or sanitary sewer, and treated at a wastewater treatment plant. Industrial development and uncontrolled increase of rural-urban migration that lead to growth of the urban population have resulted in an increase in the unavailability of good quality water resulting to drinking any water available whether is wastewater discharge from industry, which have adverse effects on human populace (4). Management problems such as poor wastewater collection, an indiscriminate disposal of wastewater.

Wastewater can originate from human waste (such as faeces, used toilet paper or wipes, urine, or other bodily fluids), also known as blackwater, usually from lavatories; Cesspit leakage; septic tank discharge, sewage treatment plant discharge, washing water (personal, clothes, floors, dishes, etc.), also known as greywater or sullage, rainfall collected on roofs, yards, hard standings, etc. (generally clean with traces of oils and fuel); groundwater infiltrated into sewage; surplus manufactured liquids from domestic sources (drinks, cooking oil, pesticides, lubricating oil, paint, cleaning liquids, etc) (7).

These effluent from industries have a great deal of influence on the pollution of the water body, these effluent can alter the physical, chemical and biological nature of the receiving water body. Increased industrial activities have led to 
pollution stress on surface waters both from industrial, agricultural and domestic sources (16).

Water of good drinking quality is of basic importance to human physiology as well as indispensable to man's continued existence (1). Its role as a medium of water borne disease which constitutes a significant percentage of the diseases that affect human and animals cannot be underestimated. This is the most important concern about the quality of water. Guideline for physicochemical composition of water differs from country to country but they all conform to WHO recommendation (8) The standards for drinking water are more stringent than those for recreational waters. Investigations of how magnetic and electric fields affect living organisms at the molecular level have revealed impacts on the biological functions of organisms via changes in the concentration of hormones, activity of enzymes, transport of ions by the cell membrane or changes in the synthesis or transcription of DNA (19).

Natural water is never absolutely pure, as it carries traces of other substances which bestow on it physical, chemical and bacteriological characteristics. The nature and amount of these substances called impurities vary with sources of the water. Although, most of the water on earth is not accessible, the surface water, which is the most accessible, represents only about $0.02 \%$ of the total water resources (6). The industrial, domestic and agricultural wastes that are discharged into this river contains harmful chemicals such as heavy metals, oil, settle able solids, nutrients and ammonia which may affect the resident species in receiving water body. In addition, plants and animals inhabiting the water body are not spared as their normal functioning and population dynamics is affected by pollution. All these effects will go back to man as its insatiable consumption of fresh water resources remains unending. Thus, man may be facing the physiological threat. Many people in developing countries like Nigeria do not have easy access to it.In 2004, the World Health Organization reported that about 1.1 billion people representing $17 \%$ of the global population were without safe drinking water. Substantial number of these people lives in China, India, Africa and Middle East. The report also had it that $42 \%$ of Sub-SaharaAfrica lacks drinking water. By the end of 2008, an estimated 884 million people in the world lacked access to improved sources of drinking water and 2.6 billion people lack access to improved sanitation facilities (18). Forecast has shown that more than $47 \%$ of the global population will face severe water hardship by the year 2030 (21). Despite increasing public sensitization, water pollution continues to generate unpleasant implication for health and community development. The protection of water quality and aquatic ecosystem as a vulnerable resource essential sustainable development is of utmost important to prevent water pollution and degradation of fresh water resources in this region. It is important to continually to develop means of having water resources management policies to prevent discharging of wastewater into the environments. Chemicals that have been used to inhibit the microorganisms can cause deteriorating effects on aquatic microbiota and humans (Aiyesanmi, 2012). better alternative that does not have adverse effect is by the use of Electromagnetic Field. This study therefore is aimed at investigating the effect on water physicochemical properties.

\section{MATERIALS AND METHODS}

\subsection{Study Area}

Akure is situated at $7.25^{\circ}$ North latitude, $5.19^{\circ}$ East longitude and 396 meters elevation above the sea level. Akure is a big town in Nigeria, having about 420,594 inhabitants. Owena which is located in the suburb of Owena town in Ifedore Local Government Area of Ondo-State, between latitude $7.15^{0} \mathrm{~N}$, longitude $5.05^{\circ} \mathrm{E}$

\subsection{COLLECTION OF WASTEWATER SAMPLE}

Wastewater sample were collected at different companies from septic tank using polyethylene bottles which was washed, rinsed with dilute nitric acid solution, and rinsed two to three times with some of the water been sampled and transported to the laboratory for experiment

\subsection{PHYSCOCHEMICAL PARAMETERS 2.3.1 DETERMINATION OF $\mathbf{p H}$}

The $\mathrm{pH}$ values of the wastewater samples were monitored using an electronic $\mathrm{pH}$ meter, (Jenway, 2015). The electrode of the $\mathrm{pH}$ meter was dipped into a beaker containing $100 \mathrm{ml}$ of buffer solution $\mathrm{pH} 4$ and $\mathrm{pH} 9$ in order to calibrate the instrument. The standardized electrode was removed from the buffer solution and rinsed with sterilized distilled water. The sample was placed into $50 \mathrm{ml}$ clean glass beaker into which an electrode of a standardized $\mathrm{pH}$ meter was inserted. The values were immediately read on the meter record and the values were recorded in triplicate (Ademoroti, 1996)

\subsubsection{DETERMINATION OF ELECTRICAL CONDUCTIVITY (EC)}

The conductivimeter used in conductivity measuring bridge type MC3 instrument. The samples were thoroughly mixed together before an aliquot was poured into the meter sample holder. Immediately the reading knob was depressed, the reading was taken and recorded for each sample. (20). 
2.3.3 DETERMINATION OF TOTAL SOLIDS, DISSOLVED SOLIDS AND SUSPENDED SOLIDS

\section{(a) Total solids}

The sample was thoroughly shaken together and $50 \mathrm{ml}$ of unfiltered sample was measured and transferred into a previously weighed evaporating dish. The dish was then placed on an electric hot plate for evaporation. After evaporation, it was dried in an oven at $105^{\circ} \mathrm{C}$, cooled in the desiccators and weighed. The drying, cooling and weighing on the balance continued until a constant weight was obtained (8).

Total solid is expressed as: total solid $(\mathrm{mg} / \mathrm{l})=\underline{\text { total solid }}$ $\underline{(\mathrm{mg}) \times 100}$

$$
\text { Sample (ml) }
$$

\section{(b) Total dissolved solids}

The sample was first filtered using a Whatman filter paper. $50 \mathrm{ml}$ of the filtrate was then transferred into a previously weighed evaporating dish. This was evaporated to dryness on an electric hot plate before drying to a constant weight in the oven at $105^{\circ} \mathrm{C}$. The weight of the dish was subtracted from the final weight to obtain the weight $(\mathrm{mg})$ of the total dissolved solids (9). Total dissolved solid $(\mathrm{mg} / \mathrm{l}=\underline{\text { Total }}$ dissolved solid $(\mathrm{mg}) \times 10)$ filtrate taken $(\mathrm{ml})$

\section{(c) Suspended solids}

Apparatus: Gooch funnel, filtering flask, oven, dessicator, vaccum pump, $100 \mathrm{ml}$ pipette.

Procedure: Dry glass filter papers, $5.5 \mathrm{~cm}$ in diameter to constant weight at $103^{\circ} \mathrm{C}-105^{\circ} \mathrm{C}$ in oven, cool to room temperature in a dessicator. Note the weight. Then prepare Gooch funnel and rubber adapter and fix to a filtering flask. Place the filter paper into the Gooch funnel carefully with the aid of a pair of tongues. Mix the water sample thoroughly and withdrawn $100-250 \mathrm{ml}$ with a pipette. Filter quickly using the filtering apparatus. Using a pair of tongues, remove the filter paper carefully from the Gooch and then dry to constant weight at $103-105^{\circ} \mathrm{C}$. Weigh it, subtract the weight of the filter paper to obtain the weight of the suspended solids (9).

Suspended Solid $(\mathrm{SS})=\underline{\text { Suspended Solid }(\mathrm{mg}) \times 100}$

Sample (ml)

\subsubsection{Determination of sulphate}

A $10 \mathrm{ml}$ of the sample was introduced into $25 \mathrm{ml}$ volumetric flask and $10 \mathrm{ml}$ of distilled water was added. This was followed by addition of $1 \mathrm{ml}$ of gelatin- $\mathrm{BaCl}_{2}$ reagent. The mixture was made up to the mark with distilled water. The mixture was allowed to stand for 30mins before the optical density was determined at 420nm (19).

Calculation

$\mathrm{SO}_{4}{ }^{2-}(\mathrm{mg} / \mathrm{l})=\underline{\text { mass of } \mathrm{SO}_{4}{ }^{2-} \text { from cruve } \times 1000 \times \mathrm{D}}$ Sample (ml)

Where $\mathrm{D}$ is the dilution factor

$\mathrm{D}=$ total volume of mixture

Sample volume

\subsubsection{Determination of biochemical oxygen demand}

Determination of the initial dissolved oxygen of the water samples, the water samples was properly shaken and $250 \mathrm{ml}$ of each sample was taken aseptically into 250 $\mathrm{ml}$ black bottle. The bottle was kept in the incubator at $20^{\circ} \mathrm{C}$ for 5 days. After 5 days of incubation, the dissolved oxygen analyzer; Model JPB-607 was used to determine the final dissolved oxygen. The analyzer was calibrated in distilled water before and after use for each sample. (Ademoroti, 1996)

The biochemical oxygen demand (BOD) was calculated as follows;

$$
\begin{array}{r}
\mathrm{BOD}=\left(\mathrm{Do}_{\mathrm{i}}-\mathrm{Do}_{\mathrm{f}}\right) \text { xvolume of bottle } \\
\text { volume of sample used }
\end{array}
$$

Where:

$$
\begin{aligned}
& \mathrm{BOD}=\text { Biochemical Oxygen Demand } \\
& \mathrm{DO}_{\mathrm{i}}=\text { Initial Dissolved Oxygen } \\
& \mathrm{DO}_{\mathrm{f}}=\text { Final Dissolved Oxygen }
\end{aligned}
$$

\subsubsection{Determination of potassium}

It's also measured with the help of flame photometer. The instrument is standardized with known concentration of potassium solution in the range of $1 \mathrm{mg}$ to $5 \mathrm{mg} / \mathrm{l}$. The sample having higher conc is suitably diluted with distilled water and dilution factor is applied to the observed values (8).

\subsubsection{Determination of chloride}

It is measured by titrating a known volume of sample with standardized silver nitrate solution using potassium chromate solution in water or eosin/fluorescein solution in alcohol as indicator. The latter indicator is an adsorption indicator while the former makes a red colored compound with silver as soon as the chlorides are precipitated from solution. (9)

2.3.8 Determination of silicates and phosphates

Apparatus: Spectrometer (Gallenkamp) 
Analytical balance, pipette, burette, standard flask and funnel.

These are also measured spectroscopically. $50 \mathrm{ml}$ of water samples were pipette into $100 \mathrm{ml}$ standard flask followed by $8 \mathrm{ml}$ of Murphey and Riley reagent and made up to mark with distilled water. The solutions were allowed to stand for 30 minutes. The absorbance of the standard and samples were read from spectrophotometer at $660 \mathrm{~nm}$. The graph of absorbance against concentration of standards were plotted and sample concentration evaluated from the graph(9).

Calculation:

$$
\mathrm{PO}_{4} \mathrm{mg} / \mathrm{l}=\text { Reading from graph } \times \frac{100}{50} \times \frac{1000}{50}
$$

\subsubsection{Determination of nitrate}

Apparatus: Spectrometer (Gallenkamp)

Analytical balance, pipette, burette, standard flask and funnel.

$0.5 \mathrm{ml}$ of samples and working standard were pipette into test tubes. $1 \mathrm{ml}$ of $5 \%$ salicyclic acid solution was added to each test tube and mixed. This was allowed to stand for 30 minutes, after which $10 \mathrm{ml}$ of $4 \mathrm{M} \mathrm{NaOH}$ solution were added. It was allowed to stand for one hour for colour development, colour stable for 12 hours. The absorbance were read from spectrophotometer at $410 \mathrm{~nm}$.

Calculation:

$\mathrm{NO}_{3}-\mathrm{N} \mathrm{mg} / \mathrm{l}=$ Reading from graph $\times \frac{11.5}{50} \times \frac{1000}{50}$

\subsubsection{DETERMINATION OF METALS}

The sample for metal analysis was prepared prior to determinadtion. $5 \mathrm{ml}$ of concentrated $\mathrm{HNO}_{3}$ was added to $200 \mathrm{ml}$ of water sample in a $250 \mathrm{~cm}^{3}$ beaker. The solution was evaporated to dryness (less than $25 \mathrm{ml}$ ). After cooling, the solution was made up to $25 \mathrm{ml}$ with conc. $\mathrm{HNO}_{3}$ and transferred into sample bottle prior to analysis (11). The heavy metals were determined with Atomic Absorption Spectrometer (AAS) by using appropriate wavelength for each. The alkali metals were determined by using flame photometer. The absorbance and the concentration of the metals in the sample were thereby obtained. (8).

\section{RESULTS AND DISCUSSION}

3.1 Physicochemical composition of wastewater

Tables 1and 2 shows physicochemical composition (i.e both physical and chemical composition) of wastewater from two different industries in Akure Metropolis. The physical parameter for raw and treatedsample or industry A has various triplicate results but the mean values are temperature $\left(26.8^{\circ} \mathrm{C}\right)$, treated $\left(25.0^{\circ} \mathrm{C}\right)$, colour $(15.00 \mathrm{pt} / \mathrm{co}$ unit), turbidity $\quad(4.65 \mathrm{FTU})$, treated $\quad(0.27 \mathrm{FTU})$,electrical conductivity $(43.00 \mu \mathrm{S} / \mathrm{cm})$ treated $\quad(0.01 \mu \mathrm{S} / \mathrm{cm})$. The physical parameter for raw sample or industry $\mathrm{B}$ hasvarious mean values temperature $\left(27^{\circ} \mathrm{C}\right)$, treated $\left(26^{\circ} \mathrm{C}\right)$, colour (19.00pt/co unit), turbidity (8.50NTU), treated $(0.01 \mathrm{NTU})$ ,electrical conductivity $(39.00 \mu \mathrm{S} / \mathrm{cm})$ treated $(0.01 \mu \mathrm{S} / \mathrm{cm})$. The chemical parameter for rawand treated sample A hasvarious mean values $\mathrm{pH}(7.74)$ treated (6.44), chloride $(18.00 \mathrm{mg} / \mathrm{l})$, treated $(8.30 \mathrm{mg} / \mathrm{l})$, Total Hardness $(382 \mathrm{mg} / \mathrm{l})$, treated $(68.20 \mathrm{mg} / \mathrm{l})$, sulphate $(15.60 \mathrm{mg} / \mathrm{l})$, treated $(6.30$ $\mathrm{mg} / \mathrm{l})$, nitrate $(7.20 \mathrm{mg} / \mathrm{l})$, treated $(4.20 \mathrm{mg} / \mathrm{l})$, Phosphate $(10.60 \mathrm{mg} / \mathrm{l})$ treated $(3.50 \mathrm{mg} / \mathrm{l})$, total solid $(276 \mathrm{mg} / \mathrm{l})$ treated $(66 \mathrm{mg} / \mathrm{l})$, Total dissolved solid $(276 \mathrm{mg} / \mathrm{l})$, treated $(66 \mathrm{mg} / \mathrm{l})$, Total soluble solid $(64.70 \mathrm{mg} / \mathrm{l})$ treated $(32.20$ $\mathrm{mg} / \mathrm{l})$, total alkalinity $(74 \mathrm{mg} / \mathrm{l})$ treated $(37 \mathrm{mg} / \mathrm{l})$ total acidity $(6.40 \mathrm{mg} / \mathrm{l})$ while treated $(2.90 \mathrm{mg} / \mathrm{l})$, sodium $(14$ $\mathrm{mg} / \mathrm{l})$, treated $(5.40 \mathrm{mg} / \mathrm{l})$, potassium $(12.10 \mathrm{mg} / \mathrm{l})$ while treated $(3.25 \mathrm{mg} / \mathrm{l})$ DO $(5.20 \mathrm{mg} / \mathrm{l})$, treated $(1.70 \mathrm{mg} / \mathrm{l})$ BOD $(9.20 \mathrm{mg} / \mathrm{l})$, treated $(4.20 \mathrm{mg} / \mathrm{l})$, COD $(13.02 \mathrm{mg} / \mathrm{l})$, treated $(5.10 \mathrm{mg} / \mathrm{l})$. The physical parameter for raw and treated sample/industry A hasvarious mean values temperature $\left(26.8^{\circ} \mathrm{C}\right)$, treated $\left(25.0^{\circ} \mathrm{C}\right)$, colour $(15.00 \mathrm{pt} / \mathrm{co}$ unit), turbidity (4.65FTU), treated (0.27 NTU),electrical conductivity $(43.00 \mu \mathrm{S} / \mathrm{cm})$ treated $(0.01 \mu \mathrm{S} / \mathrm{cm})$. The physical parameter for raw and treated sample/industry B has various mean values temperature $\left(27^{\circ} \mathrm{C}\right)$, treated $\left(26^{\circ} \mathrm{C}\right)$, colour (19.00pt/co unit), turbidity $(8.50 \mathrm{NTU})$, treated $(0.01$ NTU),electrical conductivity $\quad(39.00 \mu \mathrm{S} / \mathrm{cm})$ treated $(0.01 \mu \mathrm{S} / \mathrm{cm})$. The chemical parameter for raw and treated sample Bvarious mean values $\mathrm{pH}$ (7.65) treated (6.40), chloride $(26.08 \mathrm{mg} / \mathrm{l})$, treated $(10.46 \mathrm{mg} / \mathrm{l})$, total hardness $(990 \mathrm{mg} / \mathrm{l})$, treated $(600 \mathrm{mg} / \mathrm{l})$, sulphate $(22.20 \mathrm{mg} / \mathrm{l})$, treated $(8.50 \mathrm{mg} / \mathrm{l})$, nitrate $(6.80 \mathrm{mg} / \mathrm{l})$, treated $(6.00 \mathrm{mg} / \mathrm{l})$, Phosphate $(14.40 \mathrm{mg} / \mathrm{l})$ treated $(4 \mathrm{mg} / \mathrm{l})$, total solid $(154.50$ $\mathrm{mg} / \mathrm{l})$ treated $(51.50 \mathrm{mg} / \mathrm{l})$, total dissolved solid $(150.30$ $\mathrm{mg} / \mathrm{l})$, treated $(50.30 \mathrm{mg} / \mathrm{l})$, total soluble solid $(72.50 \mathrm{mg} / \mathrm{l})$ treated $(20.40 \mathrm{mg} / \mathrm{l})$, total alkalinity $(90 \mathrm{mg} / \mathrm{l})$ treated $(65$ $\mathrm{mg} / \mathrm{l})$ total acidity $(6.00 \mathrm{mg} / \mathrm{l})$ while treated $(2.50 \mathrm{mg} / \mathrm{l})$, sodium $(13.20 \mathrm{mg} / \mathrm{l})$, treated $(4.24 \mathrm{mg} / \mathrm{l})$, potassium $(16.30$ $\mathrm{mg} / \mathrm{l})$ while treated $(3.25 \mathrm{mg} / \mathrm{l})$ DO $(3.40 \mathrm{mg} / \mathrm{l})$, treated $(1.30 \mathrm{mg} / \mathrm{l})$ BOD $(7.50 \mathrm{mg} / \mathrm{l})$, treated $(2.50 \mathrm{mg} / \mathrm{l})$, COD $(10.95 \mathrm{mg} / \mathrm{l})$, treated $(2.50 \mathrm{mg} / \mathrm{l})$. 
TABLE.1: Statistical Analysis Physicochemical Parameters of Raw and Treated Waste Water From Industry A.

\begin{tabular}{llllll}
\hline Physical parameter & Range & Grand mean & $\begin{array}{l}\text { Standard } \\
\text { Deviation }\end{array}$ & CV\% & T cal \\
\hline Temperature $\left({ }^{\circ} \mathrm{C}\right)$ & $25.00-27.00$ & 7.07 & 0.69 & 9.77 & 1.04 \\
& & & & & Colorless \\
Colour(Pt/Co unit) & $15.45-15.55$ & 15.50 & 0.05 & 0.31 & Unobjectionable \\
& & & & & Unobjectionable \\
Taste & Objectionable & Objectionable & Objectionable & 1.11 & 1.81 \\
Turbidity $(\mathrm{NTU})$ & $0.27-4.75$ & 4.70 & 0.05 & 0 &
\end{tabular}

\section{Chemical parameters}

$\begin{array}{llllll}\mathrm{pH} & 6.41-7.74 & 7.07 & 0.69 & 9.77 & 66.27^{*} \\ \text { Chloride (mg/l) } & 8.28-18.50 & 13.16 & 5.33 & 40.5 & -89.35^{*} \\ \text { Total hardness (mg/l) } & 68.20-384.0 & 225.13 & 171.85 & 7.63 & 271.63^{*} \\ \text { Sulphate (mg/l) } & 6.00-16.20 & 10.95 & 5.11 & & \\ \text { Nitrate (mg/l) } & 4.24-7.50 & 5.75 & 1.60 & 46.68 & 24.01^{*} \\ \text { Phosphate (mg/l) } & 4.00-10.64 & 7.05 & 3.90 & 27.83 & 16.42^{*} \\ & & & & 0.55 & 24.52^{*} \\ \text { Total Solid (mg/l) } & 64.00-277.00 & 171.00 & 115.03 & 67.27 & 162.67^{*} \\ \text { Total Dissolved solids } & 55.00-256.00 & 152.7 & 106.65 & 69.85 & 79.09^{*} \\ \text { (mg/l) } & & & & & 1.75 \\ \text { Total Suspended solids } & 32.00-71.10 & 49.45 & 19.05 & 38.52 & \text { ND } \\ \text { (mg/l) } & & & & & 1.83 \\ \text { Partial Alkalinity } & \text { ND } & \mathrm{ND} & \mathrm{ND} & \mathrm{ND} & 1.06 \\ \text { Total Alkalinity (mg/l) } & 30.00-75.00 & 55.50 & 20.75 & 37.39 & 1.15 \\ \text { Total Acidity (mg/l) } & 2.85-6.43 & 4.65 & 1.92 & 41.23 & 1.15 \\ \text { Sodium (mg/l) } & 5.00-14.50 & 9.7 & 4.73 & 48.74 & 1.06 \\ \text { Potassium (mg/l) } & 3.25-12.30 & 7.69 & 4.84 & 62.95 & 1.08 \\ \text { DO (mg/l) } & 17.0-5.40 & 3.60 & 1.87 & 51.88 & 1.13 \\ \text { BOD (mg/l) } & 3.80-7.53 & 6.70 & 2.76 & 41.22 & 47.53 \\ \text { COD (mg/l) } & 4.90-10.98 & 9.03 & 4.29 & & \end{array}$

LEGEND:ND $=$ Not detected, $C V=$ Coefficient of variation; $\mathrm{cal}=\mathrm{t}$ values calculated for test of significant difference between raw and treated waste wate, $\mathrm{BOD}=$ Biological oxygen demand, $\mathrm{COD}=$ chemical oxygen demand. 


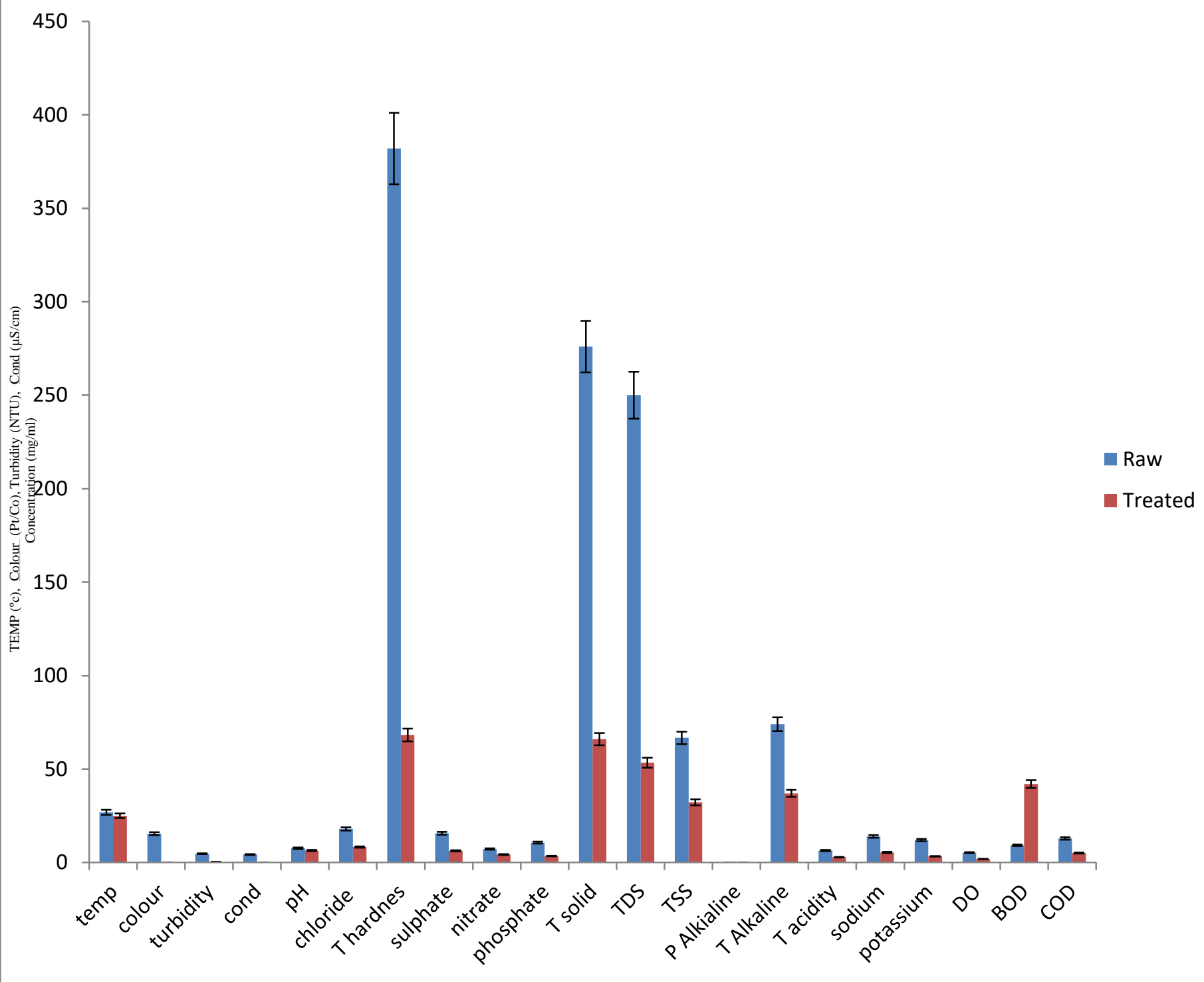

Fig.1: Physicochemical Factors Of Raw and EMF Treated Waste Water From Industry A

LEGEND : Temp $=$ Temperature, Cond $=$ Conductivity, $T=$ Total, $D O=$ Dissolve oxygen BOD=Biological oxygen demand, $C O D=$ chemical oxygen demand. 
TABLE 2: Statistical Analysis Physicochemical Parameters of Raw and Treated Waste Water From Industry B.

\begin{tabular}{|c|c|c|c|c|c|}
\hline Physical parameter & Range & Grand mean & $\begin{array}{c}\text { Standard } \\
\text { Deviation } \\
\end{array}$ & $\mathrm{CV} \%$ & T cal \\
\hline Temperature $\left({ }^{\circ} \mathrm{C}\right)$ & $26.00-27.00$ & 26.57 & 0.53 & 2.01 & 1.04 \\
\hline Colour(Pt/Co unit) & $18.50-15.55$ & 8.43 & 2.20 & 26.87 & Colorless \\
\hline Turbidity (NTU) & $0.01-8.50$ & 4.86 & 4.54 & 93.35 & 1.07 \\
\hline Conductivity $(\mu \mathrm{S} / \mathrm{cm})$ & 39.00 & 39.00 & 20.85 & 53.45 & 1.81 \\
\hline \multicolumn{6}{|l|}{ Chemical parameters } \\
\hline $\mathrm{pH}$ & $6.39-7.66$ & 7.04 & 0.671 & 9.53 & \\
\hline Chloride (mg/l) & $10.41-27.13$ & 8.43 & 2.20 & 26.12 & $66.27 *$ \\
\hline Total hardness (mg/l) & $598.0-994.0$ & 795.00 & 213.63 & 26.87 & $89.35^{*}$ \\
\hline Sulphate (mg/l) & $8.30-23.20$ & 15.35 & 7.53 & 49.07 & $271.63 *$ \\
\hline Nitrate (mg/l) & $5.50-6.85$ & 6.40 & 0.54 & 8.46 & \\
\hline \multirow[t]{2}{*}{ Phosphate $(\mathrm{mg} / \mathrm{l})$} & $4.00-14.80$ & 9.20 & 5.70 & 61.98 & $24.01 *$ \\
\hline & & & & & $16.42 *$ \\
\hline Total Solid (mg/l) & $51.45-154.8$ & 103.00 & 56.42 & 54.78 & $24.52 *$ \\
\hline Total Dissolved solids & $50.0-150.4$ & 100.30 & 2882.69 & 227.52 & \\
\hline$(\mathrm{mg} / \mathrm{l})$ & & & & & $162.67 *$ \\
\hline $\begin{array}{l}\text { Total Suspended solids } \\
(\mathrm{mg} / \mathrm{l})\end{array}$ & $20.00-74.50$ & 46.45 & 28.57 & 6150 & $79.09 *$ \\
\hline Partial Alkalinity & ND & ND & ND & ND & 1.75 \\
\hline Total Alkalinity (mg/l) & $65.00-91.00$ & 77.5 & 13.71 & 1.35 & \\
\hline Total Acidity (mg/l) & $2.00-6.43$ & 4.26 & 1.98 & 46.38 & ND \\
\hline Sodium $(\mathrm{mg} / \mathrm{l})$ & $4.21-14.50$ & 8.55 & 4.74 & 55.42 & 17.69 \\
\hline Potassium (mg/l) & $3.22-12.30$ & 9.79 & 7.14 & 72.94 & \\
\hline $\mathrm{DO}(\mathrm{mg} / \mathrm{l})$ & $1.26-5.40$ & 2.35 & 1.15 & 48.98 & 1.06 \\
\hline BOD (mg/l) & $2.43-7.53$ & 5.00 & 2.74 & 54.78 & 1.15 \\
\hline \multirow[t]{4}{*}{ COD (mg/l) } & $2.46-10.98$ & 6.73 & 4.63 & 68.82 & 1.15 \\
\hline & & & & & 1.06 \\
\hline & & & & & 1.08 \\
\hline & & & & & 1.13 \\
\hline
\end{tabular}

KEY ND = Not detected, $\mathrm{CV}=$ Coefficient of variation; $\mathrm{t}$ cal $=\mathrm{t}$ values calculated for test of significant difference between raw and treated waste water. 


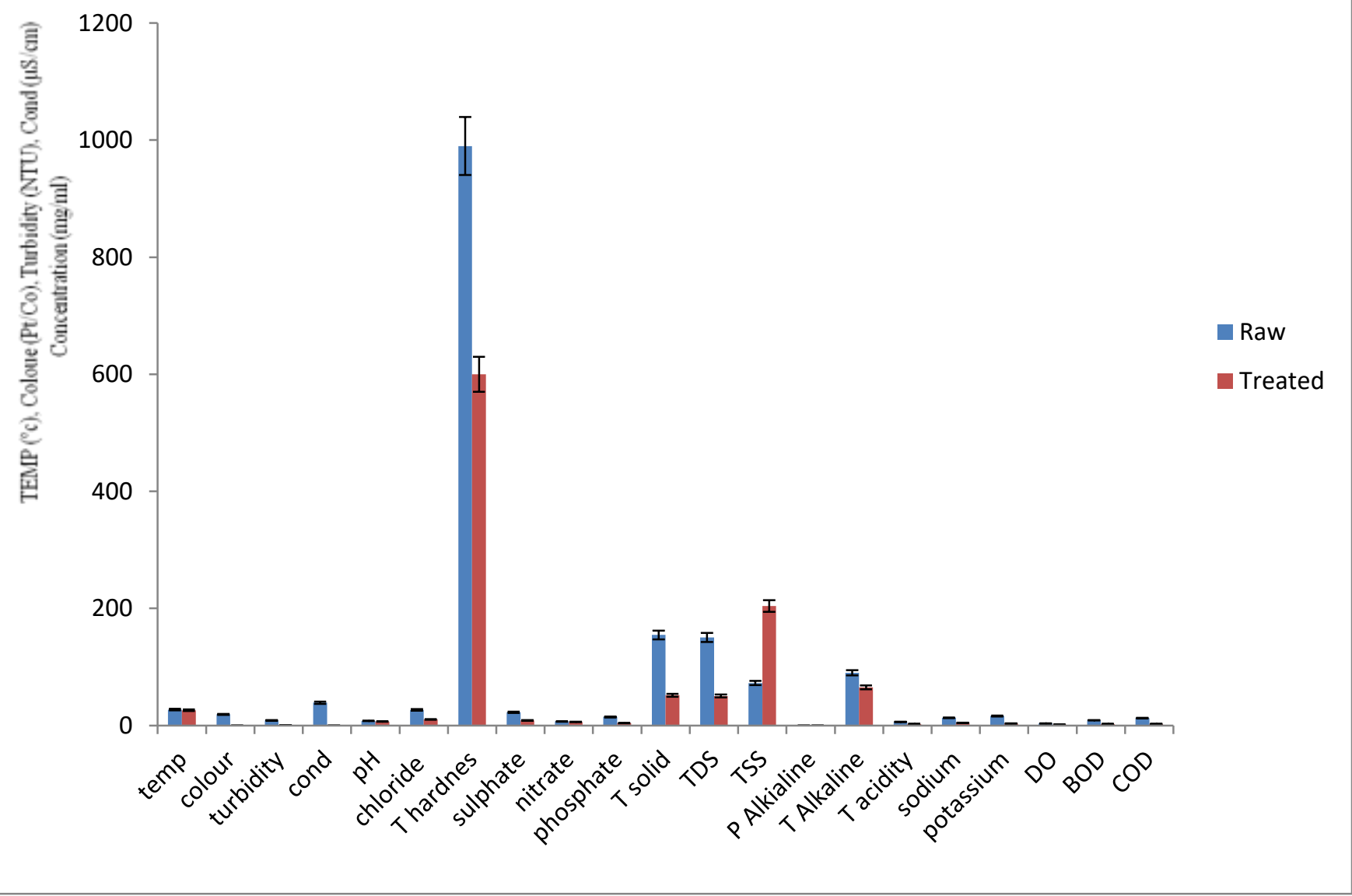

Fig.2: Physicochemical Factors Of Raw and EMF Treated Waste Water From Industry $B$

LEGEND : Temp $=$ Temperature, Cond $=$ Conductivity, $T=$ Total BOD=Biological oxygen demand, COD $=$ Chemical oxygen demand, $D O=$ Dissolve Oxygen

\subsection{Mineral composition of wastewater}

Tables 3 and 4shows mineral composition of wastewater from different food companies. The mineral composition includes the iron, zinc, lead, chromium, cadmium, copper, manganeseand Nickel. For industry A the raw and treated sample with EMF, the highest mean values are iron(1.66 $\mathrm{ppm})$, treated $(0.84 \mathrm{ppm})$, zinc $(0.42 \mathrm{ppm})$, treated (0.24ppm), copper $(0.12 \mathrm{ppm})$, treated $(0.06 \mathrm{ppm})$, nickel $(0.08 \mathrm{ppm})$, treated $(0.04 \mathrm{ppm})$, manganese $(0.06 \mathrm{ppm})$, treated $(0.04 \mathrm{ppm})$, lead, chromium and cadmium werenot detected. For industry $B$ the raw and treated sample with EMF, the highest mean values are iron $(0.53 \mathrm{mg} / \mathrm{l})$, treated (0.22 ppm), zinc $(0.24 \mathrm{ppm})$, while treated has a higher value $(1.20 \mathrm{ppm})$, manganese $(0.04 \mathrm{mg} / \mathrm{l})$, while treated has a higher value $(0.05 \mathrm{mg} / \mathrm{l})$, copper $(0.04 \mathrm{mg} / \mathrm{l})$, while treated has a higher value $(0.06 \mathrm{mg} / \mathrm{l})$, nickel has lowest mean value $(0.01 \mathrm{mg} / \mathrm{l})$, treated (not detected) lead, chromium and cadmium were not detected.The concentrations of heavy metals analysedin the waste water for both raw and treated samples. Statistical analysis of the data showed significant difference $(\mathrm{p}<0.05)$ in the mean values between the raw and treated sample for $\mathrm{Pb}, \mathrm{Cu}, \mathrm{Cr}, \mathrm{Mn}, \mathrm{Zn}$, whereas $\mathrm{Cd}$ and $\mathrm{Ni}$ Whereas Statistical analysis of the data showed no significant difference $(p<0.05)$ in the mean values between the raw and treated sample for $\mathrm{Zn}$ and $\mathrm{Fe}$ whereas $\mathrm{Cu}$ and $\mathrm{Mn}$ there was no significant difference for industry B. 
RAW

$0.12 \pm 0.02^{\mathrm{a}} \quad 0 \pm 0$

$0.47 \pm 0.02^{\mathrm{a}} \quad 1.63 \pm 0.02^{\mathrm{a}}$

$0.14 \pm 0.01^{\mathrm{a}} \quad 0 \pm 0$

$0.07 \pm 0.01^{\mathrm{a}}$

$0.14 \pm 0.02^{\mathrm{a}}$

1150nT

$0.10 \pm 0.01$

$0 \pm 0$

$0.44 \pm 0.04^{\mathrm{ab}} \quad 1.60 \pm 0.02^{\mathrm{a}}$

$0.12 \pm 0^{\mathrm{a}}$

$0 \pm 0$

$0.06 \pm 0.025^{\mathrm{a}}$

$0.12 \pm 0.02^{\mathrm{b}}$

$0.07 \pm 0.01^{\text {bc }} \quad 0 \pm 0$

$0.42 \pm 0.02^{\mathrm{ab}} \quad 1.58 \pm 0.02^{\mathrm{ab}}$

$0.10 \pm 0^{\mathrm{ab}}$

$0 \pm 0$

$0.04 \pm 0.02^{\mathrm{a}}$

$0.06 \pm 0.01^{\mathrm{b}}$

3000 n

$0.05 \pm 0.01$

$0 \pm 0$

$0.40 \pm 0.04^{\mathrm{b}}$

$1.54 \pm 02^{\mathrm{bc}}$

$0.08 \pm 0^{\mathrm{b}}$

$0 \pm 0$

$0.02 \pm 0.02^{\mathrm{a}}$

$0.05 \pm 0.01^{\mathrm{b}}$

5000nT

$0.02 \pm 0.01$

$0 \pm 0$

$0.36 \pm 0.02$

$1.50 \pm 0.02^{\mathrm{c}}$

$0 \pm 0^{\mathrm{c}}$

$0 \pm 0$

$0.024 \pm 0.02^{\mathrm{a}}$

$0.04 \pm 0.01^{\mathrm{b}}$ 
TABLE.4: Mineral Composition of Waste Water From Industry B

\begin{tabular}{|c|c|c|c|c|c|c|c|c|}
\hline SAMPLE & $\mathrm{Cu}$ & $\mathrm{Cr}$ & $\mathrm{Zn}$ & $\mathrm{Fe}$ & $\mathrm{Cd}$ & $\mathrm{Pb}$ & $\mathrm{Mn}$ & $\mathrm{Ni}$ \\
\hline RAW & $0.08 \pm 0.04^{\mathrm{a}}$ & $0 \pm 0$ & $1.40 \pm 0.02^{\mathrm{a}}$ & $0.53 \pm 0.02^{\mathrm{a}}$ & $0 \pm 0$ & $0 . \pm 0$ & $0.45 \pm 0.01^{\mathrm{a}}$ & $0.42 \pm 0.01^{\mathrm{a}}$ \\
\hline 1150nT & $0.06 \pm 0.01^{\mathrm{b}}$ & $0 \pm 0$ & $1.2 \pm 0.04^{\mathrm{b}}$ & $0.22 \pm 0.02^{\mathrm{b}}$ & $0 \pm 0$ & $0 \pm 0$ & $0.053 \pm 0.03^{b}$ & $0.40 \pm 0^{\mathrm{ab}}$ \\
\hline $1310 \mathrm{nT}$ & $0.05 \pm 0.01^{b}$ & $0 \pm 0$ & $1.08 \pm 0.02^{b}$ & $0.18 \pm 0.02^{\mathrm{bc}}$ & $0 \pm 0$ & $0 \pm 0$ & $0.034 \pm 0.02^{\mathrm{b}}$ & $0.38 \pm 0.01^{\mathrm{ab}}$ \\
\hline 3000nT & $0.04 \pm 0.01^{\mathrm{b}}$ & $0 \pm 0$ & $1.06 \pm 0.04^{b}$ & $0.14 \pm 0.02^{c}$ & $0 \pm 0$ & $0 \pm 0$ & $0.030 \pm 0.02^{\mathrm{b}}$ & $0.36 \pm 0.01^{b}$ \\
\hline $5000 \mathrm{nT}$ & $0.02 \pm 0.01^{\mathrm{b}}$ & $0 \pm 0$ & $1.02 \pm 0.02^{\mathrm{b}}$ & $0.13 \pm 0.02^{\mathrm{c}}$ & $0 \pm 0$ & $0 \pm 0$ & $0.023 \pm 0.02^{\mathrm{b}}$ & $0.03 \pm 0.01^{\mathrm{c}}$ \\
\hline
\end{tabular}

Legend: Data are presented as Mean $\pm \mathrm{SD}(\mathrm{n}=2)$ from triplicate determinations, different superscripts in the same row are significantly different $(\mathrm{P}<0.05)$

\subsection{Physicochemical Factors Of Raw and EMF Treated Waste Water From Industry A and B}

In the chemical composition the chemical parameters of wastewaters collected from the different companies, the raw wastewater without treatment collected from industry A has the highest $\mathrm{pH}$ level range, after the treatment the $\mathrm{pH}$ decreases. For industry $\mathrm{B}$ the $\mathrm{pH}$ was dwindling and after the treatment the $\mathrm{pH}$ also elided further in values. The $\mathrm{pH}$ of the water samples ranged from very slightly acidic value to slightly basic value which is identical to the findings of (21).

The $\mathrm{pH}$ of all waste water (i.e the raw and the treated) falls under the internationally recommended standard, for both surface and groundwater system. Although $\mathrm{pH}$ usually has no direct impact on consumers, it is one of the most important operational water quality parameters. Extremes of $\mathrm{pH}$ can affect the palatability of a water but the corrosive effect on distribution systems is a more urgent problem (18).The $\mathrm{pH}$ is of the utmost importance in determining the corrositivity of water (16). In general, the lower the value of $\mathrm{pH}$, the higher the level of corrosion. It has been observed that in some cases decrease in $\mathrm{pH}$ is accompanied by the increase in bicarbonate, carbonate and hydroxyl ions. Decrease in $\mathrm{pH}$ can be caused by the increase in the amount of organic carbon, total carbonate by the use of sewage.

The wastewater collected from industry A has the highest dissolved oxygen demand value from which also reduces to after application with EMF, the industry B has lower dissolved oxygen demand than industry A which the value after application with EMF also reduces which is in congruent to findings (2).

Organic wastes and other nutrient inputs from sewage and industrial discharges, agricultural and urban runoff can result in decreased oxygen levels. Nutrient input often leads 
to excessive algal growth; when the algae die, the organic matter is decomposed by bacteria, a process which consumes a great deal of oxygen that could lead to oxygen sag (2). A high DO level in a community water supply is good because it makes drinking water taste better. However, high DO levels speed up corrosion in water pipes.

3.4 Physicochemical factors of raw and emf treated waste water from industry $A$ and $B$

In the chemical composition the chemical parameters of wastewaters collected from the different companies, the raw wastewater without treatment collected from industry A has the highest $\mathrm{pH}$ level range, after the treatment the $\mathrm{pH}$ decreases. For industry $\mathrm{B}$ the $\mathrm{pH}$ was dwindling and after the treatment the $\mathrm{pH}$ also elided further in values . The $\mathrm{pH}$ of the water samples ranged from very slightly acidic value to slightly basic value which is identical to the findings of (21).

The $\mathrm{pH}$ of all waste water (i.e the raw and the treated) falls under the internationally recommended standard, for both surface and groundwater system. Although $\mathrm{pH}$ usually has no direct impact on consumers, it is one of the most important operational water quality parameters. Extremes of $\mathrm{pH}$ can affect the palatability of a water but the corrosive effect on distribution systems is a more urgent problem (9).The $\mathrm{pH}$ is of the utmost importance in determining the corrositivity of water (6). In general, the lower the value of $\mathrm{pH}$, the higher the level of corrosion. It has been observed that in some cases decrease in $\mathrm{pH}$ is accompanied by the increase in bicarbonate, carbonate and hydroxyl ions. Decrease in $\mathrm{pH}$ can be caused by the increase in the amount of organic carbon, total carbonate by the use of sewage.

The wastewater collected from industry A has the highest dissolved oxygen demand value from which also reduces to after application with EMF, the industry B has lower dissolved oxygen demand than industry A which the value after application with EMF also reduces which is in congruent to findings of (4).

Organic wastes and other nutrient inputs from sewage and industrial discharges, agricultural and urban runoff can result in decreased oxygen levels. Nutrient input often leads to excessive algal growth; when the algae die, the organic matter is decomposed by bacteria, a process which consumes a great deal of oxygen that could lead to oxygen sag (16). A high DO level in a community water supply is good because it makes drinking water taste better. However, high DO levels speed up corrosion in water pipes.

Dissolved oxygen is an important environmental parameter for the survival of aquatic life. The wastewater collected from industry A has lower biological oxygen demand value range and industry $\mathrm{B}$ had the higher biological oxygen demand from which devaluate after application with EMF, the industry. Unpolluted, natural waters should have a BOD of $(5 \mathrm{mg} / \mathrm{l}$ or less), and there are no direct health implications for BOD, but an important indicator of overall water quality according to United State Environmental Protection Agency, "Current Drinking Water Standards. So before application the waste water was polluted but after application with EMF it reduces the pollution level to unpolluted because the values fall beyond $5 \mathrm{mg} / \mathrm{l}$.

The wastewater collected the industry $\mathrm{B}$ has higher chemical oxygen demand value than Similar observation was reported on the study of chemical oxygen demand in some industries in Ado-Ekiti by (2). No direct health implications for COD, but also an important indicator of overall water quality according to United State Environmental Protection Agency, "Current Drinking Water Standards. The wastewater collected from industry A has the lower total solid value, while industry B has the higher soluble solid presence in the wastewater sample then after treatment it decreases in the value after application but also an important indicator of overall water quality which fall into $5000 \mathrm{mg} / \mathrm{l}$ similar to findings of (19) which research was done on some waste water from some industries.

The wastewater collected from industry A has the lower total dissolved solid value while industry B has the higher value of soluble solid, then after treatment both industry A and $\mathrm{B}$ values decreases consubtantial observation was reported by (17) on the study. The wastewater collected from industry A has the higher total soluble solid value between presence then after treatment it decreases while industry B has the lower soluble solid presence then after treatment it decreases in which the values was higher than industry A after treatment. Higher chloride levels were measured in the raw waste water sample A, while after. Lower chloride levels were measured in the raw waste water sample B. The consistently higher values recorded in the sample A could be as a result of concentration of this anion from excessive water evaporation from the waste water. Similar to what was recorded in this study which the values reduces after exposure to EMF, and much below the permissible drinking water standard of $250 \mathrm{mg} / \mathrm{l}$ similar to findings of (8).

Nitrate level in the raw waste water from industry A was lower in values than nitrate level in the raw wastewater from industry $\mathrm{B}$ the results was in congruent to findings of (11). Nitrate level in the raw waste water from the two industries compared to what is normally found in an unpolluted natural fresh waters, relatively little of the nitrate found in natural waters is of mineral origin, while most 
coming from organic and inorganic sources, including waste discharges and artificial fertilisers. Also, bacterial oxidation and fixing of nitrogen by plants can both produce nitrate (11). Interest is centred on nitrate concentrations for various reasons. Most importantly, high nitrate levels in waters to be used for drinking will render them hazardous to infants as they induce methaemoglobinaemia ("blue baby" syndrome).

The nitrate itself is not a direct toxicant but is a health hazard because of its conversion to nitrite, which reacts with blood haemoglobin to cause methaemoglobinaemia. Hence, $100 \mathrm{mg} / \mathrm{l}$ nitrate is set as Guideline value for nitrate in drinking water (20). The values recorded in this study were well below the guideline value suggesting that water from the dam is considered safe for drinking. In aquaculture, nitrate is considered a less serious environmental problem, it can be found in relatively high concentrations where it is relatively nontoxic to aquatic organisms, but stimulates the growth of plankton and water weeds that provide food for fish. This may increase the fish population, but when concentrations become excessive, and other essential nutrient factors are present, eutrophication and associated algal blooms can become a problem.

The significance of nitrite (at the low levels often found in surface waters) is an indicator of possible sewage pollution and as earlier mentioned, it is of concern for its toxicity. Concentrations of phosphate in the raw waste water sample A was higher values and it was lower after subjecting it to EMF which has a value of $(4.00 \mathrm{mg} / \mathrm{l})$, concentrations of phosphate in the raw waste water sample B was lower than sample A which is in range to values from (3) findings. Phosphorus from where phosphate is derived occurs widely in nature in plants, in microorganisms, in animal wastes; and large quantities of phosphate are applied as fertilizers in agriculture for which runoff from this area will often contains elevated concentrations of phosphate (9). Hence, (250 $\mathrm{mg} / \mathrm{l})$ phosphate is set as Guideline value for phosphate in drinking water (20).

Partial Alkalinity was not detected in both industries may be due to less carbonates. The total alkalinity level in the raw waste water from industry A was higher range between while the treated sample reduces in value. The total alkalinity level in the raw waste water from industry B was lower in values, while the treated sample reduces in value. Total alkalinity is a measure of the ability of the water to neutralize acids.

The constituents of alkalinity in neutral system include mainly carbonate, bicarbonate, hydroxide and other components (17). These compounds result from dissolution mineral substances in the soil and atmosphere. The carbonates was more and later becomes lesser after the application of EMF because of the values of raw and treated samples water (19). Partial Alkalinity was not detected in both industries may be due to less carbonates. The total acidity level in the raw waste water from industry A was lower ranged between while the treated sample reduces in values similar to the findings of (17). The total acidity level in the raw waste water from industry B was higher ranged between while the treated sample reduces in value, it ranged from.

The sodium level in the raw waste water from industry A was lower than treated sample reduces in value. The sodium level in the raw waste water from industry B was higher, while the treated sample reduces in value, it ranged from, which is in correlation to the finding of (12). Abnormally large concentrations may indicate natural brines, industrial brines, or sewage, so because of lower values of sodium it shows lesser concentrations of natural brines, industrial brines, or sewage even the lesser concentrations was reduced to minimal level after exposure to EMF.

The potassium level in the raw waste water from industry A was higher while the treated sample reduces in value. The sodium level in the raw waste water from industry B was lower between while the treated sample reduces in value, it ranged from, Similar results were reported by (4).

In the physical parameters, the raw waste water collected from site A has the higher temperature mean value $27{ }^{\circ} \mathrm{C}$, which reduces after the treatment with EMF to $26{ }^{\circ} \mathrm{C}$ and raw sample collected from industry $\mathrm{B}$ has the lower temperature value range, which reduces after the treatment with EMF to the mean temperature value $\left(25{ }^{\circ} \mathrm{C}\right)$ Similar (9). The temperature values of the industrial waste water fell within the optimal water temperatures (Target Guidelines) of $28{ }^{\circ} \mathrm{C}-30{ }^{\circ} \mathrm{C}$, within which maximal growth rate, efficient food conversion, best condition of fish, resistance to disease and tolerance of toxins (metabolites and pollutants) are enhanced (3).

The raw waste water without treatment collected from industry A the taste is objectionable while after the treatment with EMF the taste was unobjectional which fell under WHO standard, so exposure to EMF changes the taste to unobjectionable which is good for drinking (20).

The raw waste water collected from site $\mathrm{A}$ has the lower colour value ranged between, which reduces after the treatment with EMF to colourless, and raw sample collected from industry $\mathrm{B}$ has the lower temperature value range, Similar results were reported by (4) which reduces after the treatment with EMF to colourless. High colour units measured during before exposure to EMF can be attributed to runoff into water bodies with high entrained suspended 
suspended particles and coloured substances predominantly of organic origin. Because of its origins mostly in vegetable matter the degree of colour in a water may vary widely in space and in time. Limits for colour in potable water have traditionally been based on aesthetic considerations rather than on the basis of a health hazard, and this has been set at $15.00 \mathrm{Pt} / \mathrm{Co}$ units (20). This calls for attention because the presence of colour on a persistent basis in a water to be disinfected by chlorination is highly undesirable.

There is high tendency for the colour-causing substances to react with the added chlorine giving rise to the presence of trihalomethanes (THMs), which are potential hazards to public health (2). So it's better for industrial waste water should be disinfected with EMF instead of chlorine because of these disadvantage mention earlier (15).

The turbidity level in the raw waste water from industry A was higher while the treated sample reduces in value the turbidity level in the raw waste water from industry B was lower was while the treated sample reduces to minimal value, In addition, high turbidity can lead to an increase in the amount of disinfection byproducts (THMs) that form in treated water and could interfere with sunlight penetration, thus reducing photosynthesis. The low values after subjecting to EMF indicate that it has disinfect byproducts (THMs)(3).

The electrical conductivity value level in the raw waste water from industry A was higher than industry B. The electrical conductivity level in the raw waste water from industry B was lower was while the treated sample reduces to minimal value, it has the highest while site $\mathrm{A}$ of the treated sample has the lowest electrical conductivity value, similar to the findings of (14). The wastewater collected from industry B of the raw sample has the highest chemical oxygen demand value while industry $\mathrm{A}$ of the treated sample has the lowest chemical oxygen demand.

In the mineral and elemental composition, There is variation in the mineral composition among the raw sample and the ones treated with EMF strength. For wastewater collected from industry A, the treated sample has the higher value of iron while the raw sample has the lower iron value. For wastewater collected from industry B, The raw sample has the highest value of iron while the treated sample has the lowest iron value Similar results were reported by (6)

Wastewater collected from industry A, the raw sample has the higher value of zinc than while the treated sample, for wastewater collected from industry $\mathrm{B}$, the treated sample has the higher value of zinc ranged while the raw sample has the lower iron value which is similar to the findings of (13).Chromium was not detected in both industries in the raw and treated samples.
For wastewater collected from industry A, the raw sample has the higher value of copper while the treated sample has the lower copper value, for wastewater collected from industry $\mathrm{B}$, the treated sample has the higher value of copperSimilar observation was reported by (17). While the raw sample has the lower copper value. For wastewater collected from industry A, the raw sample has the higher value of cadmium range while the treated sample has the lower cadmium value ranged cadmium was not detected in industry B in the raw and treated samples, (9) for wastewater collected from industry A.

Lead was not detected in both industries in the raw and treated samples. For wastewater collected from industry A, the raw sample has the higher value of manganese while the treated sample has the lower cadmium value. For wastewater collected from industry $\mathrm{B}$, the raw sample has the higher value of manganese while the treated sample has the lower value of manganese, this is in agreement to the findings to (15).

For wastewater collected from industry A, the raw sample has the higher value of nickel while the treated sample has the lower cadmium value ranged while the treated sample was not detected this in agreement to the results of (5). While zinc and iron recorded higher concentrations than their guideline values but after the treatment with EMF for industry it reduces below guildlines values but in industry A it did not reduces below guildlines values but still reduce in value this in agreement to the results of (1). Toxic effects have resulted from the ingestion of large quantities of iron, but there is no evidence to indicate that concentrations of iron. The presence of some microorganisms in the waste water, hence, a maximum acceptable concentration has not been set. At concentrations above $0.3 \mathrm{mg} / \mathrm{l}$ (19). Statistical analysis of the data showed significant difference $(\mathrm{p}<0.05)$ in the mean values between the raw and treated sample for $\mathrm{Pb}, \mathrm{Cu}, \mathrm{Cr}, \mathrm{Mn}, \mathrm{Zn}$, where as $\mathrm{Cd}$ and $\mathrm{Ni}$ showed no significant difference for industry A. Whereas Statistical analysis of the data showed significant difference $(\mathrm{p}<0.05)$ in the mean values between the raw and treated sample for $\mathrm{Zn}$ and $\mathrm{Fe}$ where as $\mathrm{Cu}$ and $\mathrm{Mn}$ showed no significant difference for industry A.

\section{CONCLUSION}

From the research, it was observed that EMF treatment has a significant effect on the physicochemical parameters of the industrial wastewater.significant effect was observed on the physicochemical properties as for the the exposed wastewater to electromagnetic field but no significant effect was observed on the elemental composition of the waste water sample. The EMF treatments reduced the microbial 
population as well as the rate of contamination in the wastewater samples as the exposure time increased. It is therefore recommended that wastewater from industries should be treated with EMF before discharging them to the other water bodies so as to avoid contamination. This will help reduce microbial population that constitute a serious hazard to public health. The electromagnetic field treatments could also help protect other life forms inhabiting the water body and thus guard against ecological imbalance of the microbiota.

\section{COMPETING INTERESTS}

Authors have declared that no competinginterests exist.

\section{REFERENCES}

[1] Adefemi, SO. and Awokunmi, EE.,Determination of physicochemical parameters and heavy metals in water samples from Itaogbolu area of OndoState, Nigeria, African Journal of Environmental Science and Technology; 2010; 4(3), pp 145-148.

[2] Adefemi, OS., Olaofe.O. and Asaolu, SS. "Concentration of Heavy Metals in Water, Sediment and Fish Parts (Illisha africana) from Ureje Dam, AdoEkiti, Ekiti State, Nigeria," Journal Biology and Physical Sciences, 2004; 3, 111-114.

[3] Ademoroti, C. M. A "Environmental Chemistry and Toxicology," Foludex Press Ltd., Ibadan 1996.

[4] Adeyeye, EI. Determination of heavy metals in Illisha Africana, associated Water, Soil Sediments from some fish ponds, International Journal of Environmental Study, 1994;45 (4), 231-240.

[5] Adeyinwo,CE. Aiyesanmi, AF. and Ipinmoroti, K.O. "Baseline Water Quality Status of Rivers Within Okitipupa Southeast Belt of the Bituminous Sands Field of Nigeria," Nigerian. Journal of Science, 2006; 40: 62-71.

[6] Adnan, Amin, Taufeeq, Ahmad, Malik, Ehsanullah, Irfanullah, Muhammad, Masror, Khatak Muhammad, Ayazand Khan,. Evaluation of industrial and city effluent quality using $\mathrm{p}$ hysicochemical and biological parameters, Electronic Journal of Environmental, Agricultural and Food Chemistry, 2010; 9 (5): 931939.

[7] Agarwal, Animesh Manishand Saxen.. Assessment of pollution by Physicochemical Water Parameters Using Regression Analysis: A Case Study of Gagan River at Moradabad India, Advances in Applied Science Research, 2011; 2 (2), pp 185 -189.
[8] APHA. Standard methods for the examination of water and wastewater (20 ${ }^{\text {th }}$ Edition). Washington, DC: American Public Health Association 1998.

[9] APHA.. Standard Methods For Examination of Water and Wastewater, (19 ${ }^{\text {th }}$ Edition). American Public Health Association, Washington D. C. 1996.

[10]ASTM International. Annual Book of ASTM Standards, Water and Environmental Technology, West Conshohocken, Pennsylvania;2003; pp 6-7.

[11] Al-Bastaki, NM. Performance of advanced methods for treatment of wastewater: Chemical Engineering and Processing; 2008; 43 (7): 34

[12] Iqbal, F., Ali, AM., Salam, BA., Khan, S., Ahmad, Q. and Kashif, U. Seasonal Variations of Physicochemical Characteristics of River Soan Water At DhoakPathan Bridge (Chakwal), Pakistan,International Journal of Agriculture and Biology, 2004; 6: 89-92.

[13]Fleming and John, A.. Short Lectures to Electrical Artisans, (4 ${ }^{\text {th }}$ edition). London ;1892; pp. 38-40.

[14] Garg, V. K. Chaudhary, A., Deepshikha and Dahiya, S. An appraisal of groundwater quality in some village of district Jind. Indian Journal Environmental Protection, 1999; 19 (4) : 267-272

[15] Garric, J., Vindiman, E and Ferand, JF. Ecotoxicology and waste water, some practical implications. Sci.Total Environment (suppliment.); 1993; pp. 10851103.

[16] Okoye, BCO. Heavy Metals and Organism in the Lagos Lagoon.International Journal of Environmental Studies, 1991; .37: 285-292.

[17] Omoigberale, MO., Ogbeibu, AE. and Olotu, NO. Assessment of Groundwater Quality of Benin City, Edo State, Nigeria. Tropical Freshwater Biology;2009;18(2):15-35.

[18] World Health Organization. Chloride in DrinkingWater, Background Document for Preparation of WHO Guidelines for Drinking-Water Quality, World Health Organization, Geneva, Switzerland 2003.

[19] World Health Organisation.Water and Sanitation: Protection of the Human Environment,"World Health Organisation, Geneva, Switzerland 2014

[20] World H ealth Organization. Guideline of drinking water quality. Health Criteria and Other Supporting Information. WHO, Geneva, Switzerland. 1993;162.

[21] World Health Organization. Health guidelines for the use of wastewater in agriculture and aquaculture. Report of World Health Organization Press.Geneva, Switzerland; 1989. 